\title{
Coğrafi işaretli ürünlerin kırsal alana olan etkilerinin üreticiler açısından belirlenmesi: Finike portakalı örneği
}

\section{The determination of the effects of geographical signed products to rural area by the farmers: The example of Finike orange}

\author{
Münire ARIKAN(i), Yavuz TAŞCIOĞLU(i) \\ Akdeniz Üniversitesi, Ziraat Fakültesi, Tarım Ekonomisi Bölümü, 07070, Antalya \\ Sorumlu yazar (Corresponding author): Y. Taşcioğlu, e-posta (e-mail): ytascioglu@akdeniz.edu.tr \\ Yazar(lar) e-posta (Author e-mail): munirearikan07@ gmail.com
}

\section{MAKALE BİLGİSİ}

Alınış tarihi 02 Mayıs 2019

Düzeltilme tarihi 16 Temmuz 2019

Kabul tarihi 26 Temmuz 2019

\section{Anahtar Kelimeler:}

Coğrafi ișaret

Kirsal alan

Kirsal kalkınma

Regresyon analizi

Finike portakalı

\begin{abstract}
ÖZ
Çalışmanın amacı coğrafi işaretli ürün olan Finike portakalının bölgeye ve kırsal alana olan ekonomik etkilerinin üretici açısından belirlenmesidir. Kırsal kalkınma stratejilerinden birisi yöresel ürünlerin korumasını sağlayan coğrafi işaretli ürünlerdir. Coğrafi işaret, belli bir niteliği, ünü ve diğer özellikleriyle bir yöre, bölge veya ülke ile özdeşleşmiş bir ürünü tanıtıp, gösteren işaretlerdir. Coğrafi işaret, küçük üreticilerin ve yerel ürünlerin korunması bölgenin kalkınmasına önemli katkıları olmaktadır. Türkiye'de 2019 yılı itibari ile 1464 adet ürün coğrafi işarete sahiptir. $\mathrm{Bu}$ ürünlerden birisi olan Finike portakalı olup coğrafi işaret tanımlamasına göre üretim alanı Finike ilçesi ve mahalleridir. Finike ilçesinin toplam tarım alanı 68358 dekar olup Finike portakalının (Washington navel çeşidi) üretim alanı 30300 dekardır. Araștırmanın alanı Finike ilçesi olup ilçede 584 adet Finike portakalı üreten ișletme bulunmaktadır. Çalışmada elde dilen birincil veriler, tabaklı örnekleme yöntemine göre belirlenen 75 üretici ile yüz yüze görüşmeye dayalı anket çalışmasından elde edilmiştir. Çalışmanın sonucuna göre üreticilere göre "coğrafi işaretin bölge gelişimine katkısı vardır" önermesine katılımı en çok etkileyen demografik unsur eğitimdir. Regresyon analizi sonucunda üreticilerin eğitim seviyesi arttıkça önermeye katılımı düşmekte, eğitim seviyesi düştükçe önermeye katılımları artmaktadır.
\end{abstract}

\section{ARTICLE INFO}

Received 02 May 2019

Received in revised form 16 July 2019 Accepted 26 July 2019

\section{Keywords:}

Geographical indication

Rural area

Rural development

Regression analysis

Finike orange

\begin{abstract}
The study aims to determine the economic effects of the geo-marked product, Finike oranges, on the region and the rural areas. One of the rural development strategies is the geo-marked products that protect local products. A geographical sign is a sign indicating a product identified with a region, area or country with a certain quality, reputation and other characteristics. Geographical signs, protection of small producers and local products make a significant contribution to the development of the region. 1464 pieces of products by the year 2019 in Turkey, there are products with a geographical indication. One of these products is Finike orange, and according to the geographical sign definition, the production area is the district of Finike. The total agricultural area of Finike district is 68358 decares, and the production area of the Finike orange (Washington navel variety) is 30300 decares. The area of the study is Finike, and there are 584 Finike orange producing enterprises in the district. The primary data obtained from the study were obtained from a face-to-face questionnaire study with 75 manufacturers determined according to the stratified sampling method. At the end of the study, the demographic element that affects the participation in the producers "geographical sign contributes to regional development" statement is the level of education. As a result of the regression analysis, as the education level of the producer's increases, their participation in the proposal decreases and their participation in the proposal increases as the level of education decreases.
\end{abstract}




\section{Giriş}

Coğrafi işaretler, belirli bir alandan kaynaklanan bir ürünü tanımlayan ya da kalitesi, ünü veya diğer karakteristik özellikleri bakımından coğrafi kaynağına atfedilen, bir bölgeyi temsil eden sınaî mülkiyet hakkıdır (Ilıcalı 2005). Coğrafi işaretleri önemli kılan unsurlardan biri, içinde barındırdığ 1 anlam ve onun bir kırsal kalkınma aracı olarak küreselleşmeye karşı yerel hareketlerin teşvikini sağlayan bir olgu olarak görülmesidir.

Coğrafi işaretli ürün üretici açısından kaliteli ürün üretmenin getirdiği yüksek fiyat avantajı, tüketici açısından da aldığı ürünün belirli bir yöntemle yetiştirildiği, kaliteli olduğu ve güvenilir bir ürün olduğu algısı oluşturmaktadır. Coğrafi işaretler yerel değerlerin korunması ve sürdürülebilir olması açısından kırsal alanda kalkınmanın ekonomik araçlarından bir tanesidir.

Coğrafi işaretli ürün geleneksel yerel g1da üretimini destekleyerek, sağlıklı ürünlerin üretimine katkı sağlayacağı gibi yerel kültürün ve üretim değerlerinin de gelecek kuşaklara taşınmasına da yardımcı olacaktır. Coğrafi işaret konusu yörede üretim yapan üreticilerin, tescilini sağladığı korumadan öncelikli olarak yararlanmalarının sağlanması, coğrafi işarete konu ürünün kalitesinin koruması ve bu vasıtayla tüketici tercihleri için garanti sunan bir yol gösterici olarak görülmesi mümkündür (Tepe 2011). Coğrafi işaretleme, yöresel ürünlerin korunması, tanımlanması, tanıtılması anlamında oldukça önemli bir araç olarak da ifade edilmektedir.

Türkiye'de coğrafi işaret korunmasının yasal dayanağı 555 sayılı "Coğrafi İşaretlerin Korunması Hakkında Kanun Hükmünde Kararname" olmuştur. Yasal olarak yapılan düzenlemeler sonrasında coğrafi işaretli ürünlerle ilgili son yasal yap1 "6769 sayılı Sinai Mülkiyet Kanunu" ile belirlenmektedir (RG 1995, 2016).

Coğrafi işaretli ürünler ile kırsal kalkınma ilişkisine yönelik çeşitli çalışmalar yapılmıştır. Bu çalışmalar; Şahin ve Meral (2012), "Türkiye'de Coğrafi İşaretleme ve Yöresel Ürünler" isimli çalışmalarında, Türkiye'de coğrafi işaretlemenin önemini, kırsal kalkınmadaki rolünü mevcut verilerle ortaya koymaktadır. Kan (2011), "Yerel Düzeyde Ekonomik Kalkınmada Coğrafi İşaretlerin Kullanımı ve Etkisi: Akşehir Kirazı Araştırması" isimli çalışmasında, coğrafi işaret olarak Akşehir Kirazı'nın yerel düzeyde ekonomik kalkınma olarak kullanılma olanağını incelemiștir. Kan ve ark. (2010), "Coğrafi İşaret Olarak Karaman Divle Tulum Peyniri” isimli çalışmalarında, Karaman Divle Tulum Peyniri'nin arz zinciri ve bu zincirde yer alan önemli aktörlerin rollerinin belirlenmesi, Divle Tulum Peyniri'nin Swot Analizi yapılarak bu peynirin bölge için öneminin ve bu ürünün yörenin ekonomik kalkınmasına olası katkılarının ortaya konulmasını amaçlamışlardır. Kan ve Gülçubuk (2008), "Kırsal Ekonominin Canlanmasında ve Yerel Sahiplenmede Coğrafi İşaretler" isimli çalışmalarında, özellikle tarımda, kırsal kalkınmada Türkiye'de yeni ortaya çıkan coğrafi işaret kavramının ortaya çıkma gerekçesi hakkında bilgi verildikten sonra, coğrafi işaretlerin kırsal ekonominin canlanmasına nasıl katkıda bulunabileceğini tartışmışlardır. Oraman (2015), “Türkiye'de Coğrafi İşaretli Ürünler" isimli çalışmasında coğrafi işaretli ürünleri tanıtmış, coğrafi işarete sahip olma avantajları, başvuru için gerekli belgeler, coğrafi işaretli ürünlerin ortaya çıkışı, Türkiye'deki durum ve ekonomik öneminden bahsetmiștir. Giray ve ark. (2012), "Yerel Ürünlerin Ekonomik Kalkınmadaki Önemi" isimli çalışmasında Avrupa Birliği ve Türkiye ile ilgili mevzuat ve veri tabanlarına dayalı olarak mevcut durum, konuyla ilgili terminoloji, başvuru ve kontrol mekanizmaları incelenerek, coğrafi işaretlerin kalkınmadaki potansiyel yeri tartışılmıştır. Gökovalı (2007), "Coğrafi İșaretler ve Ekonomik Etkileri: Türkiye Örneği” isimli çalışmasında, fikri ve sınai mülkiyet haklarından biri olan coğrafi işaretlerin korunması ile ilgili tarihsel gelişimi ve coğrafi işaretlerin ekonomik etkilerini, özellikle gelişmekte olan ülkeler için irdelemiştir. Çukur ve Çukur (2017) "Coğrafi İşaretli Ürünlerin Kırsal Kalkınma Açısından Değerlendirilmesi: Muğla İli Örneği” isimli çalışmalarında, Türkiye'nin tarım ekonomisine önemli katkılar sağlayan illerinden biri olan Muğla ilinde coğrafi işaretli ürünleri çeşitli yönleri itibariyle ele alarak, kırsal kalkınma kapsamında değerlendirmişlerdir.

Coğrafi işaretli ürün kapsamında Antalya ilinde iki adet tescilli ürün bulunmaktadır. Bunlardan biri Finike portakal, diğeri ise Anamur Muzu'dur. Finike portakalının coğrafi işaret başvurusu 2000 yılında yapılmış, 2008 yılında kabul edilmiş ve Resmi Gazete'de yayınlanmıştır. Anamur muzu ise 2001 yılında coğrafi işaret başvurusu yapılmış, 2002 yılında kabul edilmiş ve Resmi Gazete'de yayınlanmıştır.

$\mathrm{Bu}$ çalışmada coğrafi işaretli ürünlerin yerel kalkınmaya etkisi çerçevesinde kırsal kalkınmaya etkileri, Finike portakalı örneği ile araştırılmıştır. Bu kapsamda coğrafi işaretli ürünün bölgeye ve kırsal kalkınmaya etkisi Finike portakalı üreten üreticilerin bakışı açısından araştırılması amaçlanmıştır. Çalışma kapsamında coğrafi işaret kavramsal olarak açıklanmış, kırsal kalkınma kavramları ilișkilendirilmiş ve kırsal kalkınmaya etkileri üretici bakışı açısından incelenmiştir.

\section{Materyal ve Yöntem}

Çalışmada birincil ve ikincil verilerden yararlanılmıştır. İkincil veriler coğrafi işaretli ürünlerle ilgili kaynaklar oluşturmuş, birincil veriler ise üreticilerle yapılan yüz yüze görüşmeye dayalı anket yönteminden elde edilmiştir.

Araştırma alanı olarak coğrafi işaretlerden menşei işareti almış olan Finike Portakalı'nın tescilde belirtilen üretim alanını oluşturan Antalya ili Finike ilçesi Turunçova, Hasyurt, Sahilkent beldesi, Yalnız ve Yuvalılar mahalleleri belirlenmiştir. Çalışmanın ana materyalini anket yoluyla elde edilen birincil veriler oluşturmaktadır. Tarım ve Orman Bakanlığı Finike İlçe müdürlüğünden alınan verilere göre mevcut bölgede Finike Portakalı'nın (Washington) üretimine yönelik 584 adet işletme bulunmaktadır. $\mathrm{Bu}$ amaçla araştırmanın yürütülmesinde; Finike Portakalı'nın (Washington) üretimi yapan tüm işletmelerde anket yapılması zaman ve maliyet açısından mümkün olmayacağı için anket yapılacak işletmeler örnekleme yöntemiyle seçilmiştir. $\mathrm{Bu}$ işletmelerin üretim alanları çeşitlilik göstermesi nedeniyle verilerin alınacağı örneklem hacmindeki işletmeler tabakalı örnekleme yönteminden, Neyman yöntemine göre örnek hacmi belirlenmiştir. Yapılan hesaplama sonucunda $\% 95$ güven sınırında 74.6 işletme çıkmıştır. Çalışmada 75 üretici ile anket çalışması yapılmıştır.

Verilerin analizinde, işletmelerin sosyo-ekonomik ve demografik özelliklerinin saptanmasında basit tanımlayıcı istatistiklerden yararlanılmıştır. Ayrıca çalışmada Finike portakalı üreticisinin coğrafi işaret almasının bölge gelişimine katkısını olup olmadığı önermesini ölçmek için aşamalı regresyon analizi uygulanmıştır.

Regresyon analizi, aralarında ilişki olan iki ya da daha fazla değişkenden birinin bağımlı değişken, diğerlerinin bağımsız 
değişkenler olarak ayrımı ile aralarındaki ilişkinin matematiksel eşitlik ile açıklanması sürecini anlatır (Tutuş ve Kılıç 2008). Regresyon analizi, bağımlı değişken ile bağımsız değişken ya da değişkenler arasındaki ilişkiyi regresyon eşitliği ile açıklamak, regresyon modelinin bilinmeyen parametreleri tahmin edildiğinde, bağımsız değişken ya da değişkenlerin bilinen değerleri için bağımlı değişkenin alacağı değeri tahmin etmek, bağımsız değişkenin ya da değişkenlerin bağımlı değișkende gözlenen değișimlerin ne kadarını açıkladıklarını, determinasyon katsayısı ile belirlemek, bağımsız değişken ya da değişkenlerin bağımlı değişkeni anlamlı bir şekilde yorumlayıp yorumlamadıklarını; birden fazla bağımsız değişken var ise bunların bağımlı değişken üzerindeki göreli önemliliklerini saptamak amacıyla yapılmaktadır (Büyüköztürk 2004).

$\mathrm{Bu}$ çalışmada üreticiye "Coğrafi işaretin bölge gelişimine katkısı vardır" önermesi bağımlı değişken olarak sorulmuş, üreticilerin demografik ve sosyo-ekonomik özellikleri bağımsız değişken olarak tanımlanmış ve aşamalı regresyon analizi uygulanmıştır.

\section{Bulgular}

\subsection{Genel Bulgular}

Kırsal kalkınma; insan yaşamına olumsuzluklar getiren kırsal çevre koşullarının iyileştirilmesine yönelik çalışmalardır. Ayrıca kırsal toplumların ekonomik ve sosyal amaçlar ile gelişmiş toplum statüsüne dönüştürüldüğü bütünleşik bir süreçtir. Kırsal kalkınma çalışmalarında, kırsal toplumların problemleri belirlenir. Bu problemlere yönelik çözüm önerileri geliştirilir. Kırsal kalkınma stratejilerinden biri olarak da yöresel ürünlerin korumasını sağlayan coğrafi işaretler düşünülebilir. Coğrafi işaretler küçük ölçekli üretim yapan aile tipi üreticilerin ve yerel ürünlerin korunması bölgenin kalkınmasına katkıları olabilecek potansiyeldedir.

Coğrafi işaret ile üreticiler kendi ürünlerini tüketicilerin gözünde hem ürün özellikleri hem de fiyatı ile farklılaştırmayı sağlamaktadırlar. Ürünlerin kendine özgü farklılıklarının olması, sağlıklı olmaları ve diğer ürünlerle karşılaşıldığında çevreye olan zararın düşük seviyede olması tüketicileri cezp etmektedir. $\mathrm{Bu}$ tür ürünlerin kendine has olan özellikleri, üretildikleri bölgeden kaynaklanan özelliği nedeniyle, hareketli olmayan bir avantaj sağlamaktadır. Bu da kırsal alanların kalkınması için bir firsat olarak değerlendirilmektedir (Callois 2004).

Kendine has özellik taşıyan bu tür ürünler, özellikle yerel zenginlikler konusunda önemli olan Türkiye'de yerel kalkınma çalışmaları için önemli avantaj oluşturmaktadır. Yerel ve kültürel mirasın korunması, geliştirilmesi kırsal turizmin de kırsal kalkınma aracı olarak kullanılmasını sağlamaktadır. Ayrıca yerel ürünlerin küresel pazarlarda ön plana çıkmasını sağlamaktadır. Yerel ürünlerin korunması ve bu ürünlerin kaynağı olan marjinal alanlarda yaşayan insanların bunun avantajından yararlanmasını sağlamak için coğrafi işaret kavramı ortaya çıkmıştır.

Coğrafi işaretlerin ekonomiye katkısı makro ve mikro olmak üzere iki başlık altında toplanabilir. Makro etkiler büyüme ve kalkınma, dış ticaret ve istihdam olarak 3 başlık altında incelenirken, mikro etkilerin tanınırlık ve pazarlama olanaklarının artması; ürün farklılaștırılmasına yol açması olarak 2 başlık altında incelenebilir (Şentürk 2011).

Coğrafi işaretlerin kırsal kalkınmada sağladığı avantajlar 5 ana başlık altında toplanabilir (Kan ve Gülçubuk 2008). a) Koruma aracı: Üreticilerin sahtecilikten dolayı gasp edilmesini ve tüketicilerin ise aldatılmasının önüne geçen bir araçtır. Ürünün haklarını, tüketicinin, üreticinin haklarını korumayı sağlar. Tüketicilerin hangi özelliklerde nerede yetiştiğini ya da yapıldığını, nerden geldiğini bildiği ürünleri tercih etmesini sağlar.

b) Pazarlama aracı: Ürünün pazardaki imajını, şöhretini ve profilini olumlu yönde etkilemektedir. Tüketicilerin coğrafi işaret almış ün yapmış olduğu ürünü almalarını sağlar. Üreticilerinde pazarlamasını iyi yapmak, ürünlerinin isimlerini korumak için daha dikkatli olarak kaliteli ürün yetiştirmelerini sağlar.

c) Kırsal kalkınma aracı: Yerel işletmelerin sürdürülebilirliğinin sağlanması, kültürel mirasın ve biyoçeşitliliğin korunması amacı ile kullanılmaktadır. Yerel işletmelerin üretiminin devamını sağlamak ve ürünlerini geliştirmek amacıyla kalkınma aracıdır.

d) Ekonomik bir denge oluşturma aracı: Az gelişmiş ve gelişmiş alanlar arasında ekonomik farklılığın giderilmesinde kullanılmaktadır. Az gelişmiş ülkelerin ürünlerinin ün yapmış olması ile ülke gelişmesine katkı sağlama aracıdır.

e) Bilgi aracı: Coğrafi işaretler üretici ve tüketici arasında bilginin ve kültürün paylaşımını sağlayan önemli bir bilgi aracidır.

\subsection{Araştırma Bulguları}

\subsection{1. Üreticilerin demografik özellikleri}

Araştırma alanı olarak Finike portakalının yetiştirilme alanı olan Finike ilçesi Turunçova, Hasyurt, Sahilkent beldesi, Yalnız ve Yuvalılar mahallelerinde üretim yapan üreticilerinin yaş, eğitim durumu, aile büyüklüğü, tarımsal faaliyet deneyim süresi, portakal üretim deneyim süresi, arazi büyüklükleri, ağaç sayıları gibi durumlar araştırılmıştır.

Araştırma alanların da yapılan 75 adet anket çalışmasının 75'i de erkek üreticiler ile yapılmıştır. Üreticilerin yaş aralıklarına bakıldığı zaman ise birinci sırada \%31.9 oranında 50-59 yaşlarında üreticiler olduğu görülmektedir. Bunu \%25.2 oranında 40-49 yaşındaki üreticiler ikinci sırada takip etmektedir. 70 üstü üreticilerin yaş oranı da \%9.3'lük kısmını kapsadığı görülmüştür. Görüşme yapılan üreticinin ortalama yaş1 50.56'dır (Şekil 1).

Türkiye'de tarım sektöründe görülen eğitim seviyesinin düşük olması olgusu Finike portakalı üreten üreticilerinde de görülmektedir. Finike portakalı üretenlerin ancak \%17'si üniversite ve yüksekokul mezunudur. Üreticilerin \%30.7 oranında ilkokul ve lise mezunu oldukları görülmektedir. Üreticilerin \%21.3 oranında da ortaokul mezunu, \%12'sinin üniversite mezunu, \%5.3 oranında da yüksekokul mezunu olduğu görülmektedir (Şekil 2).

Üreticilere hanede yaşayan kişi sayıları sorulduğu zaman, genellikle ailelerin ortalama dört kişilik aile büyüklüğüne sahip olduklarını belirtmişlerdir. Ailelerde yaşayan kişi sayıları oranladığı zaman, \%34.7 oranında dört kişilik aileler birinci sırada yer almaktadır. Bunu \%20 oranında beş kişilik aileler izlemektedir. \%17.3 oranında ailelerin üç kişilik ailede yaşadıkları görülmüştür.

Araştırma alanlarındaki üreticilere kaç yıldır tarım ile ilgilendikleri sorulmuştur. Üreticiler bu soru karşısında, genellikle çocukluktan itibaren çalıştıklarını söylemişlerdir. Ama kesin y1l sorulduğu zaman üreticilerin \% 22.6'sının 40-48 


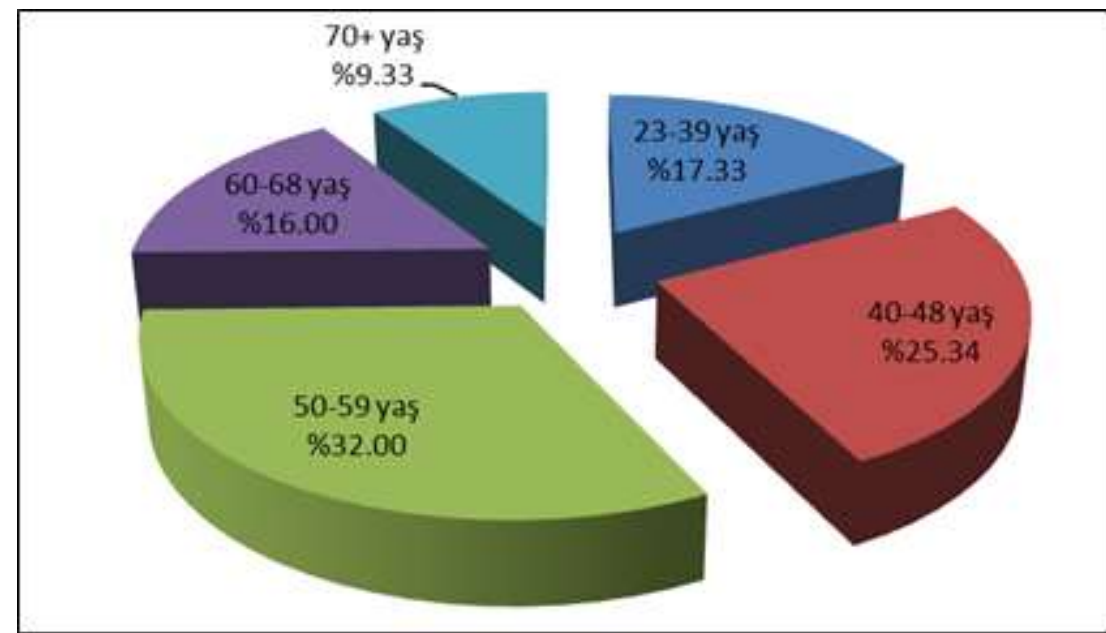

Şekil 1. Üreticilerin yaş gruplarının dağılımı.

Figure 1. Distribution of age groups of producers.

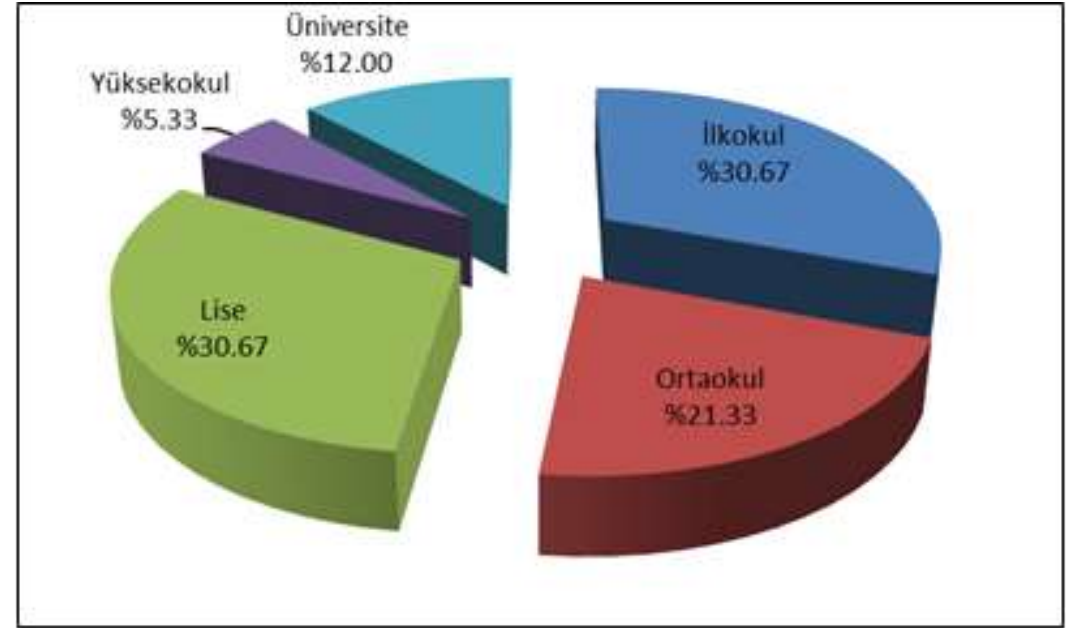

Şekil 2. Üreticilerin eğitim durumları.

Figure 2. Training status of producers.

yıllık bir deneyime sahip olduğu görülmüștür. Üreticilerin $\% 21.4$ 'ü 10-18 yıllık, üreticilerin \%19.9'u da 30-37 y1llık deneyime sahip olduğu görülmüştür. Üreticilere meyve ve portakal üretimi ile kaç yıldır ilgilendikleri de sorulmuştur. Üreticilerin \%25.3'ü 10 yıldır meyve ve portakal üretimi ile ilgilendiklerini söylerken, \%21.3'ü 30 yıldır bu işle uğraştıklarını belirtmişlerdir. Üreticilerin \%8'inin ise elli yıl ve üzeri meyve ve portakal üretimi yaptıklarını ifade etmişlerdir.

Anketlere dahil olan işletmelerin ortalama arazi büyüklüğü $47.14 \mathrm{da}$, narenciye arazilerinin ortalama büyüklüğü ise 41.20 da olarak tespit edilmiştir. İşletmelerin 50-80 da arasında toplam arazi varlığına sahip olan \%25.3'ünün en fazla payla birinci sırada yer almakta olduğu görülmüştür. Toplam narenciye üretim alanında da 1-8 dekar arasında arazi büyüklüğüne sahip olanlarının $\% 22.6$ oranıyla alan birinci sirada yer almaktadır.

Finike portakalının coğrafi işaret almış olması, üreticilerin beklentilerini karşılamadığı, ancak coğrafi işaretin kısmen de olsa ürünün tanınma alanı ve bölge tanıtımına katkısı olduğu belirtmişlerdir. Ancak üreticiler fiyat konusunda herhangi değişikliğin olmadığını dile getirmişlerdir.

\subsubsection{Analiz Sonuçları}

Çalışmanın bu aşamasında üreticilerin "Coğrafi işaretin bölge gelişimine katkısı vardır" önermesine verdikleri cevaplar bağımlı değişken olarak alınarak, üreticilerin yaşı, tarımla uğraşma yıl1, meyve üretimi ile uğraşma yılı, portakal üretimi ile uğraşma yılı, eğitim durumu, toplam arazi varlığı, toplam portakal üretim alanı varlığı, toplam ağaç sayısı ve üretim miktarı değişkenleri bağımsız değişken olarak tanımlanmış ve aşamalı regresyon analizi uygulanmıştır. Analizin sonuçları Çizelge 1'de gösterilmiştir.

Buna göre regresyon analizinin tek aşamada tamamlandığ 1 ve coğrafi işaretin bölge gelişimine katkısı vardır önermesinin varyansına katkıları bakımından, tek değişkenin önemli yorumlayıcısı olduğu görülmektedir. Analize ilk ve tek aşamada coğrafi işaretin bölge gelişimine katkısı vardır önermesine katılımının \% 7.1'ini açıklayan eğitim değişkeni alınmıştır. Yani eğitim değişkeni tek başına, üreticilerin coğrafi işaretin bölge gelişimine katkısı vardır önermesine katılımının toplam varyansının \%7.1'ini açıklamaktadır.

Coğrafi işaretin bölge gelişimine katkısı vardır önermesine katılımı en çok etkileyen demografik unsur olan eğitimdir. Buna 
Çizelge 1. Coğrafi işaretin bölge gelişimine katkısı vardır önermesine katılım.

Table 1. Geographical sign contributes to the development of the region participation in the proposal.

\begin{tabular}{lccccrrr}
\hline Demografik değişken & $\mathrm{R}$ & $\Delta \mathrm{R}^{2}$ & $\mathrm{~B}$ & $\mathrm{SH}_{\beta}$ & $\beta$ & $\mathrm{T}$ \\
\hline 1.Ĕ̈itim & 0.267 & 0.071 & -0.146 & 0.062 & -0.267 & -2.347 \\
Sabit & - & - & 4.490 & 0.29 & - & 15.502 \\
\hline Toplam: $\mathrm{R}^{2}=0.071$ & $\mathrm{~F}(1.72)=5.508$ & $\mathrm{P}=0.022$ & & & & &
\end{tabular}

karşın üreticinin yaşı, tarımsal faaliyet yapma yılı, meyve üretimi yapma yılı, toplam arazi varlığı, toplam portakal üretim alan varlığı, toplam ağaç sayısı ve üretim miktarı değişkenleri anlamlı çıkmamıştır. Bu analiz sonucunda üreticilerin coğrafi işaretin bölge gelişimine katkısı vardır önermesine katılımına aşağıdaki formülle ulaşılabilinir.

Coğrafi işaretin bölge gelişimine katkısı vardır önermesi= 4.49(Sabit)-0.146 (eğitim)

Regresyon analizi sonucunda üreticilerin eğitim seviyesi arttıkça coğrafi işaretin bölge gelişimine katkısı vardır önermesine katılımı düşmekte, eğitim seviyesi düştükçe coğrafi işaretin bölge gelişimine katkısı vardır önermesine katılımları artmaktadır.

\section{Sonuç}

Coğrafi işaret belirli bir niteliği, kaliteyi, ünü ve/veya diğer özellikleri bakımından gerek coğrafi özelliği gerekse ürün özelliğinden kaynaklanan nedenlerle diğer ürünlerden ayrımı yapılmak amacıyla ortaya çıkmış bir uygulamadır. Coğrafi işaretli ürün özelliklerinden biri, genellikle küçük ölçekli aile tipi işletmelerde üretilmesi doğrudan veya dolaylı yollarla kırsal alanla olan bağı yerel yapıyı teşvik etmesi kırsal kalkınma aracı olarak görülmesini sağlamaktadır.

Türkiye'nin de iklim ve konumu nedeniyle farklı özelliklere sahip ürün çeşitliliğinin olması da ayrıca bir avantaj olarak görülmektedir. Bu özelliklere sahip ürünlerden biri de Finike portakalıdır. Finike portakalı 2008 yılında Meyve Üreticileri Birliği'nin başvurması ile coğrafi işaret alınmıştır. Aroması ve tadı ile diğer portakallardan farklıdır. Finike portakalı bölgenin tek geçim kaynakları arasında da gösterilmektedir.

Finike portakalı coğrafi işaret özelliğinden dolayı, belirli bölgelerde üretilen portakal cinsidir. Bu nedenle bu portakalın üretiminin yapıldığı yerler dışında yapılan üretimler Finike portakalı olarak kabul edilmemektedir. Çalışmada üretim alanın kısıtlı olduğu görülmekle birlikte, üretici sayısının da kısıtlı olduğu bilinmektedir. Nitekim Finike portakalı üreten toplam işletme sayısı (584 işletme) ve ankete katılan işletmelerin ortalama genişliği (narenciye $41.20 \mathrm{da}$ ) dikkate alındığında, küçük ölçekli bir üretimin olduğu görülmektedir. Portakalın kendine özgü aroması ve tadından dolayı coğrafi işaret özelliği almış bir üründür. Coğrafi işaretin kırsal kalkınma araçlarından biri olması yerel değerlerin ortaya çıkarılması için önemlidir.

Çalışmada Finike portakalının coğrafi işaret alması ile birlikte kırsal alan etkisi üretici bakış açısına göre incelenmiştir. Üreticinin yaşı, tarımsal faaliyet yapma y1lı, meyve üretimi yapma yılı, toplam arazi varlığ varlığı, toplam ağaç sayısı ve üretim miktarı değişkenleri anlamlı çıkmamıştır. Bu karşın eğitim seviyesinde anlamlı bir sonuç çıkmıştır. Eğitim seviyesi yüksek olan üreticilerin coğrafi işaret olgusuna bakış açılarının farklı olduğu, eğitim seviyesinin düşük olduğu üreticilerin coğrafi işaret kavramına karşı bakışlarının farklı olduğu ortaya çıkmıştır. Eğitim seviyesinin yüksek olarak belirtilen üretici kesimi, coğrafi işaret kavramının bölgesel ve kırsal alana yönelik bir katk1 sağlamadığ düşüncesindedirler. Eğitim seviyesi düşük olan üretici ise coğrafi işaret alınması ile bölgesel ve kırsal alan itibariyle bir değişim yaşandığına inanmaktadır. Kalkınma olgusunun tanımlanması eğitim seviyesine göre değişmekle birlikte, bu durumun portakal üreticilerinde de görülmektedir. Coğrafi işaret ve kalkınma kavramlarının iyi tanımlanması ile doğrudan ilişkilidir. Eğitim seviyesinin yüksek olduğu kişiler ise coğrafi işaret kavramı hakkında bilgi sahibi olmalarına karşın, yörede yoğun olarak yapılan ve önemli ölçüde gelir sağlayan örtüaltı üretim faaliyetleri gibi diğer üretim faaliyetlerine göre nispeten küçük ölçekli olması, gelirinin az olması gibi nedenlerle, kırsal kalkınma çalışmalarında etkili olamayacağı düşüncelerinden dolayı, coğrafi işaretin bölge kalkınmasında etkisinin az olacağı görüşündedir.

$\mathrm{Bu}$ sonuca göre tarım sektöründe ve kırsal alanda eğitim seviyesinin düşük olsa da kırsal alanda yaşayan bireylere kırsal kalkınma olgusu anlatılmalıdır. Ayrıca yerel ve kültürel yapıya özgü öğelerin bölgesel, kırsal ve hatta ulusal kalkınmanın bir unsuru olduğu aktarılmalı, yerel yapının mevcut potansiyeli çevreyi ve doğayı bozmadan ortaya çıkarılmalı, yerel kalkınmada önemli yeri olan yöresel ürünlerin değerlendirmesi suretiyle kalkınma girişimleri teşvik edilmelidir.

\section{Teşekkür}

Akdeniz Üniversitesi Bilimsel Araştırma Projeleri Koordinasyon Birimi tarafından sağlanan maddi desteklerden dolayı teşekkür ederiz (Proje No: FYL-2016- 1707).

\section{Kaynaklar}

Büyüköztürk (2004) "Sosyal Bilimler için Veri Analizi El Kitabı İstatistik, Araştırma Deseni SPSS Uygulamaları ve Yorum”. Pegem Akademi Yayıncılık, Ankara.

Callois JM (2004) Can Quality Labels Trigger Rural Development? A Microeconomic Model With Co- Operation for he Production of a Differentiated Agricultural Good. CESAER Centre d'Economie Et Sociologie Appliquées À l'Agriculture Et Aux Espaces Ruraux BP 87999 - 26, Bd Dr Petitjean- 21079 DIJON Cedex, P:3, Working Paper 2004/6.

Çukur F, Çukur T (2017) Coğrafi İşaretli Ürünlerin Kırsal Kalkınma Açısından Değerlendirilmesi: Muğla İli Örneği. Turkish Journal of Agricultural Economics 23(2): 187-194.

Giray H, Özkan FZ, Oran H (2012) Yerel Ürünlerin Ekonomi Kalkınmadaki Önemi. T.C. Bilim Sanayi ve Teknoloji Bakanlığı, Verimlilik Genel Müdürlüğ̈̈, Verimlilik Dergisi 4: 109-115.

Gökovalı U (2007) Coğrafi İşaretler ve Ekonomik Etkileri: Türkiye Örneği. Atatürk Üniversitesi İktisadi ve İdari Bilimler Dergisi 21(2): 141-160.

Ilıcalı G (2005) Coğrafi İşaretler, Coğrafi İşaretlerde Denetim ve Denetimde Akreditasyonun Önemi. Ankara Üniversitesi, Avrupa Toplulukları Araştırma Uygulama Merkezi (ATAUM), 36. Dönem Avrupa Birliği Temel Eğitim Programı Semineri, Ankara. 
Kan M, Gülçubuk B (2008) Kırsal Ekonominin Canlanmasında ve Yerel Sahiplenmede Coğrafi İşaretler. Uludağ Üniversitesi, Ziraat Fakültesi Dergisi 22(2): 57-66.

Kan M, Gülçubuk B, Kan A, Küçükçongar M (2010) Coğrafi İșaret Olarak Karaman Divle Tulum Peyniri. Karamanoğlu Mehmetbey Üniversitesi Sosyal ve Ekonomik Araştırmalar Dergisi 12(9): 1523.

Kan M (2011) Yerel Düzeyde Ekonomik Kalkınmada Coğrafi İşaretlerin Kullanımı ve Etkisi: Akşehir Kirazı Araştırması. Ankara Üniversitesi Fen Bilimleri Enstitüsü Tarım Ekonomisi Anabilim Dalı, Doktora Tezi, Ankara.

Oraman Y (2015) Türkiye'de Coğrafi İşaretli Ürünler. Balkan ve Yakın Doğu Sosyal Bilimler Dergisi 01(01): 76-85.

RG (1995) T.C. Başbakanlık Resmi Gazete 27.06.1995 tarih 22326 sayılı "Coğrafi İşaretlerin Korunması Hakkında Kanun Hükmünde Kararname" Ankara.
RG (2016) T.C. Başbakanlık Resmi Gazete 10.01.2017 tarih 29944 sayılı "6769 sayılı Sınai Mülkiyet Kanun” Ankara.

Şahin A, Meral Y (2012) Türkiye'de Coğrafi İşaretleme ve Yöresel Ürünler. Türk Bilimsel Derlemeler Dergisi 5(2): 88-92.

Sentürk B (2011) Coğrafi İsaretlerin Ekonomik Etkileri: Mikro ve Makro Açıdan Bir Değerlendirme. Muğla Üniversitesi Sosyal Bilimler Enstitüsü, Yüksek Lisans Tezi, Muğla.

Tepe S (2008) Coğrafi İșaretlerin Ekonomik Etkileri. Uzmanlık Tezi, Türk Patent Enstitüsü Markalar Dairesi Başkanlığı, s. 160, Ankara.

Tutuş M, Kılıç, AM (2008) Çukurova Yöresinde Bulunan Bazı Mermerlere Ait Fiziko-Mekanik Özelliklerin İstatistiksel Analizi. Çukurova Üniversitesi Fen Bilimleri Enstitüsü Cilt:17-8. 